\title{
Faktor-Faktor yang Memengaruhi Risiko Investasi pada Perusahaan di Jakarta Islamic Index
}

\author{
Kartawati Mardi \& Soraya \\ Jurusan Akuntansi, Politeknik Negeri Pontianak \\ Jalan Ahmad Yani Pontianak 78124 \\ E-mail: kartawatimardiah@ymail.com
}

\begin{abstract}
Abstrak
Tujuan penelitian ini adalah untuk menguji apa kah current ratio, debt to asset ratio, debt to equity ratio, dan net profit margin berpengaruh terhadap Beta saham pada perusahaan yang terdaftar di Jakarta Islamic Index selama periode 2014-2016. Metode sampel yang digunakan adalah purposive sampling, dari metode tersebut diperoleh empat belas sampel. Hasil penelitian menunjukkan bahwa current ratio, debt to asset ratio, debt to equity ratio, dan net profit margin secara simultan tidak berpengaruh terhadap Beta Saham Syariah. Secara parsial, current ratio, debt to asset ratio, debt to equity ratio, dan net profit margin juga tidak berpengaruh terhadap beta saham syariah pada perusahaan yang terdaftar di Jakarta Islamic Index.
\end{abstract}

Keywords: current ratio, debt to equity ratio, debt to asset ratio, net profit margin, beta saham syariah

\section{PENDAHULUAN}

Indonesia adalah negara dengan penduduk Muslim terbesar di dunia, namun belum mempunyai bank syariah yang besar. Hal ini dikatakan Rini Mariani Soemarni, Menteri Badan Usaha Milik Negara (Suryowati, 2015). Hampir sama dengan pernyataan Rini, Jusuf Kalla menyatakan Indonesia terlambat mengembangkan ekonomi syariah. Menurut Jusuf Kalla, saat ini baru lima persen sistem keuangan syariah di Indonesia. Angka ini jauh lebih rendah jika dibandingkan Malaysia yang sudah menerapkan sistem keuangan syariah sebesar 22 persen (Setiawan, 2017). Oleh karena itu penelitian ini akan meneliti perkembangan ekonomi syariah khususnya di bidang investasi dalam saham syariah.

Investasi dalam saham syariah dapat dilakukan di perusahaan-perusahaan yang termasuk dalam indeks saham syariah, misalnya Jakarta Islamic Index (JII). JII merupakan indeks yang dikeluarkan oleh PT Bursa Efek Indonesia (BEI) bekerja sama dengan PT Danareksa Investment Management pada tahun 2000 (Julduha dan Kusumawardhani, 2013). JII dipilih sebagai obyek penelitian karena JII merupakan indeks saham syariah pertama di Indonesia.

Sekuritas di pasar modal syariah sama dengan pasar modal konvensional, dan setiap sekuritas syariah juga sama-sama memiliki tingkat return dan risiko seperti yang terjadi pada sekuritas-sekuritas di pasar modal konvensional. Semakin tinggi return yang disyaratkan maka semakin tinggi pula risiko yang terkandung dari suatu sekuritas. Return dan risiko selalu mengalami perubahan pada setiap saat. Berubahubahnya return dan risiko disebabkan oleh beberapa faktor yaitu faktor fundamental yang merupakan faktor-faktor yang berasal 
dari dalam perusahaan, misalnya adanya pemogokan, tuntutan pihak lain, penelitian yang tidak berhasil, kinerja perusahaan (tingkat profitabilitas, tingkat likuiditas, leverage, dividen, asset growth, ukuran perusahaan, dan lain-lain) dan faktor ekonomi yaitu faktor-faktor yang berasal dari luar perusahaan, misalnya tingkat suku bunga yang berlaku, tingkat inflasi, perubahan nilai kurs, perubahan Gross Domestic Product (GDP), dan lain-lain (Aruzzi dan Bandi, 2003). Menurut Halim, 2005 (dalam Julduha dan Kusumawardhani, 2013), dalam konteks portofolio, risiko dibedakan menjadi dua, yaitu risiko sistematik (systematic risk) dan risiko tidak sistematik (unsystematic risk). Risiko sistematik merupakan risiko yang tidak dapat dihilangkan dengan melakukan diversifikasi, karena fluktuasi risiko ini dipengaruhi oleh faktor-faktor makro yang dapat memengaruhi pasar secara keseluruhan, sehingga sifatnya umum dan berlaku bagi semua saham dalam bursa saham yang bersangkutan. Risiko tidak sistematik merupakan risiko yang dapat dihilangkan dengan diversifikasi, karena risiko ini hanya ada dalam satu perusahaan atau industri tertentu. Dengan demikian seorang investor perlu melakukan analisis tentang risiko saham untuk mengukur risiko dengan menggunakan koefisien Beta saham. Beta adalah pengukur risiko sistematik dari suatu sekuritas atau portofolio relatif terhadap risiko pasar. Beta suatu sekuritas menunjukkan kepekaan tingkat keuntungan suatu sekuritas terhadap perubahanperubahan pasar (Halim, 2005 dalam Julduha dan Kusumawardhani, 2013).

"Penelitian mengenai variabel fundamental yang berpengaruh terhadap return dan Beta saham syariah antara lain dilakukan oleh Aruzzi dan Bandi (2003) yang menunjukkan bahwa rasio profitabilitas dan Beta akuntansi tidak berpengaruh signifikan terhadap Beta saham syariah. Penelitian Hamzah (2005) menunjukkan bahwa kurs rupiah terhadap dollar dan Produk Domestik Bruto signifikan pada tingkat $5 \%$, leverage dan profitabilitas signifikan pada tingkat $10 \%$. Sedangkan karakteristik perusahaan, industri dan variabel ekonomi makro terhadap return dan Beta (Auliyah dan Hamzah, 2006), memiliki pengaruh yang signifikan terhadap Beta saham syariah. Fidiana (2006) mengungkapkan bahwa secara parsial leverage, earning variability, price book value dan volume perdagangan berpengaruh signifikan terhadap Beta saham syariah. Suhadi (2008) menguji tingkat suku bunga, inflasi dan perubahan nilai kurs dan hasilnya menunjukkan bahwa secara bersama- sama berpengaruh positif signifikan terhadap Beta saham syariah" (Julduha dan Kusumawardhani, 2013).

Penelitian ini merupakan replikasi penelitian Julduha dan Kusumawardhani (2013), dengan menambah satu variabel bebas, yaitu debt to equity ratio (DER), namun menghilangkan variabel tingkat suku bunga. Periode penelitian adalah 2014-2016, sementara periode penelitian Julduha dan Kusumawardhani (2013) adalah periode 2009-2011. Variabel penelitian Julduha dan Kusumawardhani (2013) adalah net profit margin (NPM), current ratio (CR), debt to asset ratio (DAR), dan tingkat suku bunga. Dengan demikian variabel-variabel bebas dalam penelitian ini adalah current ratio (CR), debt to asset ratio (DAR), debt to equity ratio (DER), dan net profit margin (NPM), dan variabel terikat adalah Beta saham syariah. 
Julduha dan Kusumawardhani (2013) menguji kembali penelitian Suhadi (2008) dengan mengganti tiga variabel kinerja perusahaan di antaranya yaitu net profit margin, current ratio, debt to asset ratio karena ketiga variabel ini memengaruhi risiko (Beta) saham, hal ini disebabkan seorang investor dalam memilih alternatif investasi akan cenderung memilih investasi yang menguntungkan, jika perusahaan mempunyai kemampuan dalam menekan biaya-biaya operasional perusahaan, jika perusahaan mampu memenuhi kewajiban jangka pendek serta komitmen pembayaran keuangannya dan jika perusahaan menunjukkan berapa bagian aset yang mampu digunakan untuk menjamin utangnya. Hamzah (2005) menyatakan bahwa secara bersama-sama variabel fundamental profitabilitas berpengaruh signifikan terhadap Beta saham syariah. Sebagian besar profitabilitas perusahaan akan berubah apabila terjadi perubahaan kondisi ekonomi, hal ini mengakibatkan berfluktuasinya penjualan dan menyebabkan fluktuasi pada laba yang dihasilkan. Sehingga hal ini berkaitan dengan risiko yang akan ditanggung.

Ulupui (2004) dalam Julduha dan Kusumawardhani (2013) menunjukkan bahwa current ratio memiliki pengaruh yang positif dan signifikan terhadap return saham. Hal ini mengindikasikan bahwa pemodal akan memperoleh return yang lebih tinggi jika kemampuan perusahaan memenuhi kewajiban jangka pendeknya semakin tinggi. Tingkat likuiditas perusahaan yang tinggi akan mengakibatkan harga saham naik dan jika harga saham naik maka akan mengakibatkan return yang diterima investor menjadi meningkat. Return yang tinggi akan mengakibatkan risiko investasi juga tinggi. Apabila perusahaan yang memiliki rasio likuiditas tinggi akan diminati para investor dan akan berimbas pula pada harga saham yang cenderung akan naik karena tingginya permintaan.

Kenaikan harga saham ini mengindikasikan meningkatnya kinerja perusahaan dan hal ini juga akan berdampak pada investor karena mereka akan memperoleh tingkat pengembalian yang tinggi dari investasinya. Penelitian Fidiana (2006) menunjukkan secara parsial leverage berpengaruh signifikan terhadap Beta saham syariah. Leverage digunakan untuk meningkatkan hasil pengembalian pemegang saham, tetapi dengan risiko akan meningkatkan kerugian, makin besar leverage yang digunakan oleh suatu perusahaan makin besar pula ketidaktetapan atau naik-turunnya hasil pengembalian. Suhadi (2008) menunjukkan bahwa tingkat suku bunga yang ditunjukkan oleh tingkat suku bunga SBI secara bersama-sama berpengaruh signifikan terhadap Beta saham syariah. Tingkat suku bunga merupakan hal penting dan salah satu faktor yang memengaruhi risiko investasi. Jika tingkat suku bunga tinggi, maka akan mengakibatkan harga saham turun dan risiko investasi menjadi menurun. Sebaliknya, jika tingkat suku bunga rendah, maka akan mengakibatkan harga saham naik dan risiko investasi menjadi meningkat. Jogiyanto (2010) mengetahui Beta suatu sekuritas merupakan hal yang penting untuk menganalisis sekuritas atau portofolio karena Beta menunjukkan kepekaan tingkat keuntungan suatu sekuritas terhadap perubahan-perubahan pasar. Penelitian untuk mengetahui faktor-faktor yang mempengaruhi Beta atau risiko sistematik merupakan hal yang menarik untuk 
dilakukan karena sifat dari risiko ini yang akan selalu melekat pada setiap investasi terutama investasi dalam saham biasa. Perusahaan yang terdaftar di Jakarta Islamic Index dimaksudkan untuk digunakan sebagai tolok ukur (benchmark) mengukur kinerja suatu investasi pada saham yang berbasis syariah. Melalui indeks ini diharapkan dapat meningkatkan kepercayaan investor untuk mengembangkan investasi secara syariah. Investasi pada saham yang berbasis syariah berguna untuk investor agar dapat berinvestasi di bursa saham sesuai ketentuan syariah Islam tanpa takut dengan dana ribawi, tidak bersifat spekulatif atau judi dan semua transaksi transparan.

\section{TINJAUAN PUSTAKA}

\section{Beta Saham}

Beta merupakan suatu pengukur volatilitas return suatu sekuritas atau return portofolio terhadap return pasar. Beta sekuritas ke-i mengukur volatilitas return sekuritas ke-i dengan return pasar. Beta portofolio mengukur volatilitas return portofolio dengan return pasar. Dengan demikian Beta merupakan pengukur risiko sistematik dari suatu sekuritas atau portofolio relatif terhadap risiko pasar (Jogiyanto, 2016). Beta suatu sekuritas atau portofolio ditunjukkan dengan koefisien Beta yang diukur dengan slope yang diperoleh dari regresi return saham dengan return pasar. Beta $=1$, artinya bahwa setiap satu persen perubahan return pasar baik naik ataupun turun maka return saham atau portofolio juga akan bergerak sama besarnya mengikuti return pasar. Saham yang mempunyai nilai Beta > 1 dikatakan sebagai saham agresif, artinya tingkat kepekaan saham tersebut terhadap perubahan pasar sangat tinggi atau dapat juga dikatakan memiliki risiko yang lebih besar dari tingkat risiko rata-rata pasar. Saham yang mempunyai Beta $<1$ mengindikasikan bahwa saham bersifat defensif (conservative), artinya saham tersebut kurang peka terhadap perubahan pasar dan memiliki risiko di bawah rata-rata pasar. Beta saham merupakan hasil regresi antara return perusahaan yang dihitung dari perubahan harga saham perusahaan pada akhir bulan dengan return pasar yang dihitung dari perubahan rata-rata bulanan IHSG setiap akhir tahun. Beta saham sebagai variabel dependen diukur menggunakan persamaan dari market model sebagai berikut (Jogiyanto, 2016):

$$
\mathrm{R}_{\mathrm{i}}=\alpha_{\mathrm{i}}+\beta \mathrm{i} . \mathrm{RM}+\mathrm{e}_{\mathrm{i}}
$$

Notasi:

$\mathrm{R}_{\mathrm{i}} \quad=$ Return sekuritas ke-i;

$\alpha_{i} \quad=$ Konstanta;

$\beta_{\mathrm{i}} \quad=$ Beta sekuritas ke-i

$\mathrm{RM}=$ Return portofolio pasar;

$\mathrm{e}_{\mathrm{i}} \quad=$ residual selama periode $\mathrm{t}$

Penghitungan return pasar dilakukan menggunakan persamaan:

$$
\mathrm{RM}=\left(\mathrm{RM}_{\mathrm{t}}-\mathrm{RM}_{\mathrm{t}-1}\right) / \mathrm{RM}_{\mathrm{t}-1}
$$

Notasi:

$\mathrm{RM}=$ Return pasar;

$\mathrm{RM}_{\mathrm{t}}=$ IHSG pada tahun $\mathrm{t}$;

$\mathrm{RM}_{\mathrm{t}-1}=$ IHSG pada tahun $\mathrm{t}-1$.

Untuk return saham $\mathrm{R}_{\mathrm{i}}$ dihitung berdasarkan harga saham individual tahunan.

$$
\mathrm{Ri}=\left(\mathrm{Pi}_{\mathrm{t}}-\mathrm{Pi}_{\mathrm{t}-1}\right) / \mathrm{Pi}_{\mathrm{t}-1}
$$

Notasi:

$\mathrm{Ri}=$ Return saham;

$\mathrm{Pi}_{\mathrm{t}}=$ Harga saham penutupan tahun $\mathrm{t}$;

$\mathrm{Pi}_{\mathrm{t}-1}=$ Harga saham penutupan tahun $\mathrm{t}-1$;

\section{Current Ratio}

Current ratio merupakan salah satu 
rasio yang digunakan untuk mengukur likuiditas atau kemampuan perusahaan untuk memenuhi kewajiban jangka pendek tanpa menghadapi kesulitan. Semakin besar current ratio menunjukkan semakin tinggi kemampuan perusahaan dalam memenuhi kewajiban jangka pendeknya. Unsur-unsur yang mempengaruhi nilai current ratio adalah aset lancar dan utang jangka pendek. Aset lancar (current assets) adalah kas dan aset lain yang secara wajar dapat direalisasi sebagai kas atau dijual atau digunakan selama satu tahun. Akun neraca biasanya memasukkan kas, efek yang jatuh tempo dalam satu tahun fiskal ke depan, piutang, persediaan dan beban dibayar di muka sebagai aset lancar. Utang jangka pendek (current liabilities) merupakan kewajiban yang diharapkan akan dilunasi dalam waktu yang relatif pendek, biasanya satu tahun. Kewajiban lancar mencakup utang usaha, wesel bayar, pinjaman bank jangka pendek, utang pajak dan beban yang masih harus dibayar (Surbramanyam dan John, 2011). Current ratio dapat dihitung dengan rumus:

$$
\text { Current ratio }=\frac{\text { Current assets }}{\text { Current liabilities }}
$$

\section{Debt to Equity Ratio (DER)}

Debt to Equity Ratio (DER) atau leverage menggambarkan penggunaan utang jangka pendek dan utang jangka panjang perusahaan dalam membiayai asetnya dengan tujuan dapat meningkatkan profitabilitas perusahaan. Semakin tinggi leverage perusahaan maka semakin tinggi penggunaan utang dalam struktur modal. Bagi investor perusahaan dengan leverage yang tinggi merupakan sinyal bahwa perusahaan berisiko karena terdapat kemungkinan bahwa perusahaan akan diambil alih oleh kreditor. Artinya, semakin tinggi rasio kecukupan utang, semakin tinggi risiko yang dihadapi perusahaan. Ukuran risiko yang seringkali digunakan adalah risiko gagal bayar utang atau kewajiban. Jika rasio kecukupan utang suatu perusahaan tinggi, berarti beban utang perusahaan juga tinggi, sehingga kemampuan perusahaan dalam membayar utangnya jika dikaitkan dengan aset atau modal perusahaan menjadi sulit. Oleh karena itu perusahaan harus mampu menjaga agar rasio kecukupan utangnya berada dalam batas-batas yang dapat diterima, khususnya oleh pihak pemberi dana.

\section{Debt to Equity Ratio (DER)} merupakan rasio leverage atau solvabilitas yang digunakan untuk membandingkan total utang yang dimiliki perusahaan dengan modal sendiri. (Martono dan Harjito, 2008:54 dalam Soeroso, 2013).

Hasil penelitian Grahani (2013) menyebutkan bahwa DER tidak berpengaruh secara parsial pada risiko sistematis. Namun menurut Andayani (2010) DER berpengaruh secara signifikan terhadap risiko sistematis saham atau Beta.

\section{Net Profit Margin (NPM)}

Rasio profitabilitas merupakan rasio yang bertujuan mengetahui kemampuan perusahaan dalam menghasilkan laba selama periode tertentu dan juga memberikan gambaran tentang tingkat efektifitas manajemen dalam melaksanakan kegiatan operasinya. Profitabilitas merupakan suatu indikator karakteristik perusahaan yang dilakukan manajemen dalam mengelola kekayaan perusahaan yang ditunjukkan oleh laba yang dihasilkan. Secara garis besar laba yang dihasilkan dari kemampuan perusahaan dan sumber yang ada seperti kegiatan 
penjualan, kas, jumlah karyawan, jumlah cabang dan investasi yang dilakukan oleh perusahaan (Syafri, 2008). Menurut Alexandri (2008) net profit margin adalah rasio yang digunakan untuk menunjukkan kemampuan perusahaan dalam menghasilkan keuntungan bersih setelah dipotong pajak. Net Profit Margin merupakan salah satu jenis ratio profitabilitas untuk menilai serta mengukur posisi keuangan perusahaan dalam suatu periode tertentu atau untuk beberapa periode. Cara pengukuran rasio ini adalah membandingkan laba bersih setelah pajak dengan penjualan bersih. Menurut Bastian dan Suhardjono (2006) apabila net profit margin rasionya tinggi ini menunjukkan kemampuan perusahaan menghasilkan laba yang tinggi pada tingkat penjualan tertentu, sebaliknya kalau rasionya rendah menandakan penjualan yang terlalu rendah untuk tingkat biaya tertentu, atau biaya yang terlalu tinggi untuk tingkat penjualan tertentu. Rasio yang rendah bisa menunjukkan ketidakefisienan manajemen. Rasio ini mengukur kemampuan perusahaan dalam menghasilkan laba setelah pajak dikurangi pajak pada tingkat penjualan tertentu, yang dirumuskan sebagai berikut:

$$
\mathrm{NPM}=\frac{\text { Laba bersih }}{\text { Penjualan }}
$$

Penelitian ini memperjelas hasil dari penelitian terdahulu tentang pengaruh current ratio (CR), debt to asset ratio (DAR), debt to equity ratio (DER), dan net profit margin (NPM) terhadap Beta saham syariah. Berdasarkan penelitian terdahulu hipotesis alternatif yang diajukan dalam penelitian ini adalah hipotesis sebagai berikut:

$\mathrm{H} 1$ : current ratio $(C R)$, debt to asset ratio $(D A R)$, debt to equity ratio (DER), dan net profit margin (NPM) secara simultan berpengaruh secara signifikan terhadap Beta saham syariah pada perusahaan yang terdaftar di Jakarta Islamic Index.

H2: current ratio $(C R)$, debt to asset ratio (DAR), debt to equity ratio (DER), dan net profit margin (NPM) secara parsial berpengaruh secara signifikan terhadap Beta saham syariah pada perusahaan yang terdaftar di Jakarta Islamic Index.

\section{METODE PENELITIAN}

Penelitian ini menggunakan data sekunder yang diperoleh dari database website Bursa Efek Indonesia yaitu www.idx.co.id. Data saham syariah diperoleh dari Jakarta Islamic Index (JII). Populasi penelitian ini adalah seluruh perusahaan publik yang terdaftar di BEI dan termasuk ke dalam kelompok perusahaan berbasis syariah yang tergabung dalam Jakarta Islamic Index, mulai tahun 20142016. Metode pemilihan sampel adalah dengan purposive sampling, dengan kriteria sebagai berikut; (1) terdaftar di Jakarta Islamic Index (JII) selama periode 20142016, (2) perusahaan emiten menerbitkan laporan keuangan dari tahun 2014-2016 dan memiliki kelengkapan data. Variabel yang digunakan dalam penelitian ini adalah Beta saham sebagai variabel dependen. Current Ratio (CR), Debt to Asset Ratio (DAR), Debt to Equity Ratio (DER), dan Net Profit Margin (NPM) sebagai variabel independen.

Data dikumpulkan dari berbagai sumber yang saling melengkapi seperti laporan keuangan dan ringkasan profil kinerja (performance profile) perusahaan yang diunduh dari website BEI 
(http://www.idx.co.id), serta harga saham bulanan dari situs http://finance.yahoo.com.

Analisis data yang digunakan untuk menguji hipotesis adalah analisis regresi berganda. Persamaan regresi dalam penelitian ini adalah:

$$
\mathrm{Y}=\mathrm{a}_{0}+\mathrm{b}_{1} \mathrm{CR}+\mathrm{b}_{2} \mathrm{DAR}+\mathrm{b}_{3} \mathrm{DER}+\mathrm{b}_{4} \mathrm{NPM}+\mathrm{e}_{\mathrm{i}}
$$

Notasi:

$\mathrm{Y}=$ Beta saham syariah;

$\mathrm{X}_{1} \quad=$ Net Profit Margin;

$\mathrm{X}_{2} \quad=$ Current Ratio;

$\mathrm{X}_{3}=$ Debt to Asset Ratio;

$\mathrm{X}_{4} \quad=$ Debt to Equity Ratio;

$\mathrm{e}_{\mathrm{i}} \quad=$ error term

Pengujian regresi dapat dilakukan setelah model penelitian ini memenuhi syarat-syarat yaitu lolos uji asumsi klasik, bahwa data harus berdistribusi normal, tidak mengandung multikolinearitas, heteroskedastisitas dan autokorelasi. Untuk itu sebelum melakukan pengujian regresi berganda, terlebih dahulu dilakukan pengujian asumsi klasik. Hasil uji asumsi klasik pada penelitian ini menunjukkan data berdistribusi normal dan tidak terjadi multikolinearitas, heterokedastisitas dan autokorelasi.

\section{HASIL}

Berdasarkan hasil uji ANOVA atau uji $F$ pada Tabel 6. diperoleh $F$ hitung adalah 2,368 dengan tingkat signifikansi 0,130. Oleh karena probabilitas 0,130 lebih besar dari 0,05 maka model regresi tidak dapat digunakan untuk memprediksi Beta saham. Atau dengan kata lain, CR, DAR, DER, dan NPM secara bersama-sama tidak berpengaruh terhadap Beta saham. Berarti Hipotesis (H1) bahwa current ratio (CR), debt to asset ratio (DAR), debt to equity ratio (DER), dan net profit margin (NPM) secara simultan berpengaruh secara signifikan terhadap Beta saham syariah pada perusahaan yang terdaftar di Jakarta Islamic Index (JII) tidak bisa diterima.

\section{Tabel 6. Hasil Uji F}

\begin{tabular}{lrrrrr}
\multicolumn{6}{c}{ ANOVA $^{\mathbf{b}}$} \\
\hline Model & $\begin{array}{c}\text { Sum of } \\
\text { Squares }\end{array}$ & df & $\begin{array}{c}\text { Mean } \\
\text { Square }\end{array}$ & F & Sig \\
\hline 1 Regression & 1,777 & 4 & 0,444 & 2,368 & $0,130^{\mathbf{a}}$ \\
Residual & 1,689 & 9 & 0,188 & & \\
Total & 3,466 & 13 & & & \\
\hline
\end{tabular}

a. Predictors: (Constant), NPM, CR, DER, DAR

b. Dependent Variable: BETA

Tabel 7. Hasil Uji t

Coffecients $^{\mathbf{a}}$

\begin{tabular}{|c|c|c|c|c|c|}
\hline \multirow[t]{2}{*}{ Model } & \multicolumn{3}{|c|}{$\begin{array}{c}\text { Unstandardized Standardized } \\
\text { Coefficients } \quad \text { Coeficients }\end{array}$} & \multirow{2}{*}{$\mathrm{t}$} & \multirow{2}{*}{ Sig } \\
\hline & B & $\begin{array}{l}\text { Std. } \\
\text { Error }\end{array}$ & Beta & & \\
\hline 1 (Constant) &,- 068 & 1,215 & &,- 056 &,- 056 \\
\hline CR &,- 001 & ,002 &,- 235 &,- 614 &,- 614 \\
\hline DAR & 3,136 & 3,456 & ,982 & 907 & ,907 \\
\hline DER & - & ,855 & $-1,356$ & - & - \\
\hline NPM & 1,298 & 020 &, 569 & 1,519 & 1,519 \\
\hline & .041 & & & 1,987 & 1,987 \\
\hline
\end{tabular}

a. Dependent Variable: BETA

Berdasarkan hasil Uji t pada tabel 7. dapat menggambarkan persamaan regresi, yaitu:

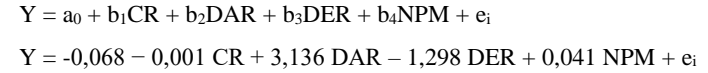

Berdasarkan hasil uji t pada Tabel 7. dapat diambil simpulan bahwa semua variabel bebas karena probabilitasnya lebih besar dari 0,05 maka model regresi tidak dapat digunakan untuk memprediksi Beta saham. Atau dengan kata lain, CR, DAR, DER, dan NPM secara parsial tidak berpengaruh terhadap Beta saham. Namun secara parsial variabel NPM hampir berpengaruh terhadap Beta saham karena signifikansinya 0,078 hanya sedikit lebih besar daripada 0,05. Hal ini hampir sesuai dengan hasil penelitian Julduha dan 
Kusumawardhani (2013) yang menyatakan bahwa NPM berpengaruh terhadap Beta saham syariah yaitu tingkat signifikansi NPM $0,003<0,005$.

Hasil penelitian ini untuk variabel DER sesuai dengan hasil penelitian Grahani (2013) yang menyebutkan bahwa DER tidak berpengaruh secara parsial pada risiko sistematis atau Beta. Namun menurut Andayani (2010) DER berpengaruh secara signifikan terhadap risiko sistematis saham atau Beta.

\section{PEMBAHASAN}

Hasil penelitian (uji F) ini berbeda dengan hasil penelitian Julduha dan Kusumawardhani (2013), yang menyatakan bahwa CR, DAR, NPM, dan Tingkat Suku Bunga secara simultan berpengaruh terhadap Beta Saham Syariah.

Hasil penelitian (uji t) ini untuk variabel DER sesuai dengan hasil penelitian Grahani (2013) yang menyebutkan bahwa DER tidak berpengaruh secara parsial pada risiko sistematis atau Beta. Namun menurut Andayani (2010) DER berpengaruh secara signifikan terhadap risiko sistematis saham atau Beta.

\section{SIMPULAN}

Dari analisis data diperoleh kesimpulan yaitu secara simultan, current ratio (CR), debt to asset ratio (DAR), debt to equity ratio (DER), dan net profit margin (NPM) tidak berpengaruh signifikan terhadap beta saham syariah pada perusahaan yang terdaftar di Jakarta Islamic Index. Sedangkan secara parsial, current ratio (CR), debt to asset ratio (DAR), debt to equity ratio (DER), dan net profit margin (NPM) juga tidak berpengaruh terhadap beta saham syariah pada perusahaan yang terdaftar di Jakarta Islamic Index.
Penelitian ini juga memiliki keterbatasan antara lain, dalam penelitian ini pengukuran beta saham untuk setiap perusahaan yang terdaftar di Jakarta Islamic Index tiap tahun menggunakan periode bulanan. Selain itu keterbatasan lainnya adalah besarnya adjusted $R$ square sebesar 0,296 atau $29,6 \%$ yang berarti masih ada faktor lain yang mampu menjelaskan beta saham syariah sebesar $70,4 \%$.

\section{REFERENSI}

Andayani, Nining Setyowati Dwi, dkk. (2010). Pengaruh Variabel Internal dan Eksternal Perusahaan Terhadap Risiko Sistematis Saham pada Kondisi Pasar yang Berbeda (Studi pada Saham-saham LQ 45 di Bursa Efek Jakarta). Jurnal Wacana Vol. 13 No. 2.

Aruzzi, M. Iqbal dan Bandi. (2003). Pengaruh Tingkat Suku Bunga, Rasio Profitabilitas dan Beta Akuntansi terhadap Beta Saham Syariah di Bursa Efek Jakarta. Simposium Nasional Akuntansi VI, Hal 647-658.

Auliyah, R. dan A. Hamzah. (2006). Analisa Karakteristik Perusahaan, Industri danEkonomi Makro Terhadap Return dan Beta Saham Syariah Di Bursa Efek Jakarta. Simposium Nasional Akuntansi 9 Padang, 2006.

Ghozali, Imam. (2013). Aplikasi Analisis Multivariate dengan Program IBM SPSS 21 Up Date PLS Regresi. Edisi 7. Semarang: Badan Penerbit Universitas Diponegoro.

Grahani, Hedwig Ajeng. (2013). Analisis Faktor-faktor yang Berpengaruh terhadap Risiko Sistematis Saham (Studi Empiris pada Perusahaan yang Tercatat dalam Indeks Kompas 100 di Bursa Efek Indonesia Januari 2008Januari 2013). Jurnal Proceeding 
Pesat (Psikologi, Ekonomi, Sastra, Arsitektur \& Teknik Sipil.

Gujarati, D.N. (2006). Essentials of Econometrics. Mc Graw Hill Companies, Inc. (Terjemahan Julius A. Mulyadi, Dasar-dasar Ekonometrika. Edisi Ketiga, Jilid 1. Jakarta: Penerbit Erlangga).

Hamzah, Ardi. (2005). Analisa Ekonomi Makro, Industri dan Karakteristik Perusahaan terhadap Beta Saham Syariah. Simposium Nasional Akuntansi VIII.

Jogiyanto. (2016). Teori Portofolio dan Analisis Investasi. Edisi Kesepuluh. Yogyakarta. BPFE.

Julduha, Nucifera dan Indra Kusumawardhani. (2013). Pengaruh Net Profit Margin, Current Ratio, Debt To Asset Ratio dan Tingkat Suku Bunga Terhadap Beta Saham Syariah Pada Perusahaan Yang Terdaftar Di Jakarta Islamic Index. Jurnal Buletin Studi Ekonomi, Vol. 18, No. 2, Agustus 2013.

Raharjo, Sahid. (2014). Uji Multikolonieritas dengan Melihat Nilai Tolerance dan VIF SPSS. Tersedia online: https://www.spssindonesia.com/2014/ 02/uji-multikolonieritas-denganmelihat.html.

Raharjo, Sahid. (2017). Cara Mengatasi Masalah Autokorelasi dengan Uji Run Test dalam SPSS. Tersedia online: https://www.spssindonesia.com/2017/ 03/autokorelasi-dengan-uji-run-testspss.html.

Setiawan, Sakina Rakhma Diah. (2017). "Wapres: Indonesia Terlambat Kembangkan Ekonomi Syariah", Artikel. Kompas.com. 11 November 2017. Tersedia online: https://ekonomi.kompas.com/read/20 17/11/10/060600326/-wapres-- indonesia-terlambat-kembangkanekonomi-syariah. [Diakses 5 Mei 2018; 10:54]

Subramanyam, K.R, dan John J. Wild. (2011). Analisis Laporan Keuangan. Jakarta: Salemba Empat.

Suryowati, Estu. 2015. "Rini: Indonesia Negara Muslim Terbesar, tetapi Tak Punya Bank Syariah yang Besar", Artikel. Kompas.com. 6 Maret 2015. Tersedia online: https://bisniskeuangan.kompas.com/re ad/2015/03/06/113600726/Rini.Indon esia.Negara.Muslim.Terbesar.tetapi.T ak.Punya.Bank.Syariah.yang.Besar.

Soeroso, Anditya. (2013). Faktor Fundamental (Current Ratio, Total Debt to Equity Ratio, Total Asset Turn Over, Return on Investment) terhadap Risiko Sistematis pada Industri Food and Beverages di Bursa Efek Indonesia. Jurnal Emba. 